Asian Journal of Managerial Science

ISSN: 2249-6300 Vol.8 No.1, 2019, pp. 16-19

(C)The Research Publication, www.trp.org.in

\title{
A Study on Women Entrepreneurs in Samayapuram, Tiruchirappalli District, Tamil Nadu
}

\author{
P. Sundari ${ }^{1}$ and G. Gannasekaran ${ }^{2}$ \\ ${ }^{1}$ Associate Professor, Department of Economics, Seethalakshmi Ramaswami College, Tiruchirappalli, Tamil Nadu, India \\ ${ }^{2}$ Associate Professor \& Head (Rtd.), Department of Economics, St.Joseph's College, Tiruchirappalli, Tamil Nadu, India \\ E-Mail: sundsrc@gmail.com
}

\begin{abstract}
The research paper "A study on women entrepreneurs in Samayapuram, Tiruchirappalli district", attempts to find out the reasons for starting business by women entrepreneurs in the study area and also analyses the various business avenues open and utilize by women entrepreneurs. The paper also throws light on the income earned by women entrepreneurs and how they supporting other sources of income. It also analyse a problems faced by women entrepreneurs and the Government support for women entrepreneurs to start a business of their own. Finally a paper comes with some important findings, which are relevant to the progress of women entrepreneurship in the study area.
\end{abstract}

Keywords: Women Entrepreneurs, Business, Entrepreneurship

\section{INTRODUCTION}

Women entrepreneur is a person who accepts challenging role to meet her personal needs and become economically independent. A strong desire to do something positive is an inbuilt quality of entrepreneurial women, who is capable of contributing values in both family and social life. The emergence of women entrepreneurs and women owned firms and their significant contributions to the economy is visible in India. The number of women entrepreneurs has increased, especially during the 1990's. The new generation of women-owned enterprises is actively seeking capital for their business, using modern technology to find create a niche in both the domestic and export markets. While women-owned businesses possess the potential and are capable of contributing much more. It is essential to formulate strategic support and sustain their efforts in the right direction. "An enterprise owned and controlled by a women having a minimum financial interest of 51 per cent of the capital and giving at least 51 per cent of the employment generated by the enterprise by women". (Government of India, 1990). A women entrepreneur can be defined as confident, innovative and creative woman capable of achieving self economic independence individually or in collaboration, generates employment opportunities for others through initiating, establishing and running the enterprise by keeping pace with her personal, family and social life. (Kamal Singh, 1992).

\section{WOMEN ENTREPRENEURS IN INDIA}

In the 70s and 90s the women in India were hardly engaged in any type of self employment. During this period the women were attracted towards various opportunities of employment in different banks, LIC, teaching jobs, etc. They were also found in the low productive sectors like agriculture and house hold activities. A woman engaging in entrepreneurial activities like medium and small scale enterprise was a remote idea. They were perceived as a homemaker and an idea that a woman can take up entrepreneurial activity was a joke. It was predominantly a male dominated field till the rise of 90s. After the introduction of the policy of liberalization, privatization and globalization, the women started responding to the changes in the environment and their entry in the entrepreneurial activities were noticed. The process of computerization also was an aid for women in their way. The beginning period marked the existence of women in the businesses related to home made products like pickles and papads. But later the focus was shifted towards the entrepreneurial activities related to the small and medium enterprises related to the manufacturing, trading and service sector (Pulla Rao D, 2012).

The term entrepreneur has its origin in the French language. In the $16^{\text {th }}$ and $17^{\text {th }}$ century this term was used in relation to the military expeditions and civil engineering activities. Later on in the $18^{\text {th }}$ century this term was used in context to the economic activities. In the late $19^{\text {th }}$ and early $20^{\text {th }}$ centuries, entrepreneurs were frequently not distinguished from managers and were viewed mostly from an economic perspective. Joseph Schumpeter's vision on entrepreneur is as follows:

The function of the entrepreneur is to reform or revolutionize the pattern of production by exploiting an invention or, more generally, an untried technological method of producing new commodity or producing an old one in new way, opening a new source of supply of materials or a new outlet for products, by organizing a new industry. Entrepreneurship is an economic activity which is undertaken by individual or group of individuals. Entrepreneurship can be defined as the making of a "new combination" of already existing materials and forces; that entrepreneurship throws up as innovations, as opposed to inventions and that no one is entrepreneur forever, only when he or she is actually doing the innovative activity. (Joseph Schumpeter, 1950). 
Entrepreneurship - the entrepreneurial function can be conceptualized as the discovery of opportunities and the subsequent creation of a new economic activity via the creation of new organization (Reynolds, 2005). "Entrepreneurship is a process by which individuals either on their own or their organizations pursue opportunities" (Stevenson and Jarillo, 1990)

\section{REVIEW OF LITERATURE}

Latha Krishnan and Kamalanabhan T.J (2013) in their study entitled "Entrepreneurial success and life satisfaction among women entrepreneur in micro-enterprises" have discussed that with the right attitude and competencies, they have proved to be successful in their small business ventures, which has brought to be better standard of living to their families and in some cases their employees too. This business Endeavour and success also gave the women entrepreneurs a great sense of pride and self satisfaction, creating an identity, respect and status within their surroundings. Perhaps most importantly these women are models for other women within their family, friends, community and society. Despite several odds prejudices and lack of a level of playing field these courageous enterprises. Women have concluded that adopted the right mix of attitude and competencies to bring about entrepreneurial success in their business and also life satisfaction on themselves and on their families.

Santhi M and Nagananthini N (2014) in their article focused, "The role and involvement of Government agencies and financial institutions in the development of women entrepreneurship in Madurai District", had focused there was gradual increase in availing subsidy by women entrepreneurs during the period of three years from 2009 to 2012. Public sector loan disbursal to women entrepreneurs was relatively higher than loan from other financial institutions. Women entrepreneurs had attended Entrepreneurship Development Programme training and skill Up-grading programmes. Thus large number of women entrepreneurs had taken term loan and working capital assistance under the single window scheme. So that Government should take steps to up-grade women entrepreneurs.

Sushma Bavie and Apoorva Palkar (2015) made a study on "Women Entrepreneurship towards women Empowerment in India: Plan Initiatives", An essential pre-requisite for women empowerment is their economic empowerment. Entrepreneurial activities by Indian women can contribute immensely towards making them economically independent and self-reliant. Globally, it is accepted that the level of entrepreneurship in a country is the index of its development. Entrepreneurship has a unique feature of not only providing employment to the entrepreneur but also providing employment to many others. It is a key to economic sustainability and growth of a nation.

Kavita Sangolagi and Mallikarjun (2016) made a study on "Women entrepreneurs" In India the business scenario is changing day by day due to the development of technology, modernization, industrialization, urbanization, spread of education and development programs initiated by the government. In such conditions, employment opportunity increased drastically for women. In India the past image of restricted and home bound women is slowly going under change. The Indian women even after facing many Challenges she is now trying to become economically independent. Government has come forward with many facilities, concessions and incentives exclusively for women entrepreneur. General measures can be adopted to encourage and develop women entrepreneurship. As even illiterate Women have the potential and the determination to set up, uphold and supervise her own enterprises in a very systematic manner. The right kind of assistance from family, society and Government can make these Roti making women entrepreneurs a part of the mainstream of national economy and they can contribute to the economic progress of the country.

Kavita Sangolagi and Mallikarjun (2018) in their article focused on women entrepreneurs definitely can become noteworthy performer and contributor to the society in general and family in particular if they could explore and these entrepreneurs are supported by government and voluntary organization either to change the attitude of the family member towards women entrepreneurship. Since this is one of the few studies on women entrepreneurs in developing district of Backword region, these results will form the basis for future research to enable more to be made known about women entrepreneurs in Kalaburagi district.

\section{OBJECTIVES OF THIS STUDY}

1. To study the age and educational qualification of the women entrepreneurs in the study area

2. To study the nature of business and income earned by the women entrepreneurs

3. To study the reason for starting own business

4. To examine specific problems faced by the women entrepreneurs in the study area

\section{AREA OF THE STUDY}

The study area is Samayapuram which is situated in Mannachanallur Taluk of Tiruchirappalli District.

\section{METHODOLOGY}

This study is based on both primary data and secondary data. Primary data have been collected from 100 sample women entrepreneurs those who are engaged in their personal business like tailoring shop, petty shop, mobile restaurant fancy stores, Xerox shop at random with help of structured questionnaire and personal interview method in Samayapuram, Tiruchirappalli District. Secondary data have been collected from various books, journals, magazine and website. 


\section{DATA ANALYSIS AND INTERPRETATION}

The potential growth of the country is indicated by the age structure. The age composition of the respondents is necessary to find out whether they are actively participated in their work or not.

TABLE I Age Wise ClassificAtion OF THE RESPONDENTS

\begin{tabular}{|c|l|c|c|}
\hline S. No. & Age (years) & $\begin{array}{c}\text { Number of } \\
\text { Respondents }\end{array}$ & Percentage \\
\hline 1 & 20 to $30 \mathrm{yrs}$ & 21 & 21 \\
\hline 2 & 30 to $40 \mathrm{yrs}$ & 32 & 32 \\
\hline 3 & 40 to $50 \mathrm{yrs}$ & 25 & 25 \\
\hline 4 & 50 to $60 \mathrm{yrs}$ & 17 & 17 \\
\hline 5 & 60 to $70 \mathrm{yrs}$ & 5 & 5 \\
\hline & Total & 100 & 100 \\
\hline
\end{tabular}

From the above table it is inferred that $21 \%$ of the respondents belong to the age group of 20 to 30 years, $32 \%$ of the respondents belong to the age group of 30-40 years, $25 \%$ of the respondents belong to the age group of 40 to 50 years, $17 \%$ of the respondents belong to the age group of 50 to 60 years. Only $5 \%$ of the respondents belong to the age group of 60 to 70 years. It is inferred that the age group of 30 to 40 years is the most important age group which has great passion for entrepreneurs. So age is very important factor to determine their responsibility and business activity.

TABle Ii EdUCATIONAL QUALIFICATION OF THE RESPONDENTS

\begin{tabular}{|c|l|c|c|}
\hline $\begin{array}{c}\text { S. } \\
\text { No. }\end{array}$ & $\begin{array}{c}\text { Educational } \\
\text { Status }\end{array}$ & $\begin{array}{c}\text { No. of } \\
\text { Respondents }\end{array}$ & Percentage \\
\hline 1 & Graduate & 28 & 28 \\
\hline 2 & Primary Level & 15 & 15 \\
\hline 3 & Secondary Level & 37 & 37 \\
\hline 4 & Illiterate & 20 & 20 \\
\hline & Total & 100 & 100 \\
\hline
\end{tabular}

Education plays a vital role in the economic development of a country. Education develops one's personality and knowledge. Education is the gateway to economic security and opportunity for women. It is an instrument for increasing women employment and empowerment. Women entrepreneurs are highly educated and empowered this will result in eradication of poverty as well as removal of inequality in this society.

$28 \%$ of the respondents studied up to graduation. $15 \%$ of the respondents studied up to primary school level. $37 \%$ of the respondents studied up to secondary level and $20 \%$ of the respondents are illiterate. This table shows that majority of the respondents are educated. Educational level of the respondents helps them to conceive a business plan and execute it.
TABLE III NATURE OF BUSINESS By THE WOMEN ENTREPRENEURS

\begin{tabular}{|c|c|c|c|}
\hline $\begin{array}{l}\text { S. } \\
\text { No. }\end{array}$ & Nature of the Activity & $\begin{array}{c}\text { No. of } \\
\text { Respondents }\end{array}$ & Percentage \\
\hline 1 & Tailoring shop & 8 & 8 \\
\hline 2 & Mobile restaurant & 10 & 10 \\
\hline 3 & Flower vendors & 5 & 5 \\
\hline 4 & Fancy store & 10 & 10 \\
\hline 5 & Petty shop & 6 & 6 \\
\hline 6 & Medical shop & 6 & 6 \\
\hline 7 & Milk Product sale & 5 & 5 \\
\hline 8 & Photoshop & 4 & 4 \\
\hline 9 & Cool drinks shop & 8 & 8 \\
\hline 10 & Street vendors & 5 & 5 \\
\hline 11 & Vegetable vendors & 4 & 4 \\
\hline 12 & $\begin{array}{l}\text { Snacks items } \\
\text { production }\end{array}$ & 5 & 5 \\
\hline 13 & Browsing centre & 7 & 7 \\
\hline 14 & Xerox shop & 6 & 6 \\
\hline 15 & Cloth sale & 6 & 6 \\
\hline 16 & Beauty parlors & 2 & 2 \\
\hline 17 & Watch shop & 1 & 1 \\
\hline 18 & Book stall & 1 & 1 \\
\hline \multirow[t]{2}{*}{19} & Ice cream shop & 1 & 1 \\
\hline & Total & 100 & 100 \\
\hline
\end{tabular}

Women entrepreneurs engaged in business due to push and pull factors which encourage them to have an independent occupation and stand in by their own leg. The following table explains the nature of business done by the women entrepreneurs. All respondents are doing different types of business activities which results in development of the society. Among them nearly $10 \%$ of the respondents are engaged in mobile restaurant and fancy store. The economic background, support of the family members, educational qualification and family business generally help women entrepreneurs to venture in to business awareness.

TABLE Iv Monthly InCOME OF THE RESPONDENTS

\begin{tabular}{|c|l|c|c|}
\hline $\begin{array}{c}\text { S. } \\
\text { No. }\end{array}$ & \multicolumn{1}{|c|}{$\begin{array}{c}\text { Monthly Income } \\
\text { (in Rupee) }\end{array}$} & $\begin{array}{c}\text { No. of } \\
\text { Respondents }\end{array}$ & Percentage \\
\hline 1 & Below Rs.5,000 & 45 & 45 \\
\hline 2 & Rs.5,001 to 10,000 & 21 & 21 \\
\hline 3 & Rs.10,001 to 15,000 & 19 & 19 \\
\hline 4 & Rs.15,001 to 20,000 & 10 & 10 \\
\hline 5 & Above Rs.20,001 & 5 & 5 \\
\hline & Total & 100 & 100 \\
\hline
\end{tabular}

Monthly income is an important measuring rod of the respondents' economic status. Income is the consumption and saving opportunity gained by an entity with in a specific 
time. It is expressed in monetary term. The women entrepreneurs earn a sizeable income which will supplement the family income. $45 \%$ of the respondents' monthly income is below Rs. 5,000, $21 \%$ is Rs.5,001 to $10,000,19 \%$ is Rs. 10,001 to $15,000 /, 10 \%$ is Rs. 15,001 to 20,000 and $5 \%$ of the respondents' monthly income is above Rs.20,001.

TABLE V REASON For STATING OWN BUSINESS

\begin{tabular}{|c|l|c|c|}
\hline $\begin{array}{c}\text { S. } \\
\text { No. }\end{array}$ & $\begin{array}{c}\text { Reason for Starting } \\
\text { Own Business }\end{array}$ & $\begin{array}{c}\text { No. of } \\
\text { Respondents }\end{array}$ & Percentage \\
\hline 1 & To uplift the family & 15 & 15 \\
\hline 2 & Divorce & 4 & 4 \\
\hline 3 & To earn money & 35 & 35 \\
\hline 4 & $\begin{array}{l}\text { To gain economic } \\
\text { independence }\end{array}$ & 26 & 26 \\
\hline 5 & To become an owner & 20 & 20 \\
\hline & Total & 100 & 100 \\
\hline
\end{tabular}

The above table revealed that $15 \%$ of the respondents start the business to uplift the family, $35 \%$ of the respondents start their own business for the purpose of earning money, $26 \%$ of the respondents start the venture for being economically independent. $20 \%$ of the respondents start the business enterprises to become a proud owner, only $4 \%$ of the respondents due to divorce they survive the life time to start the business. So entrepreneurship helps women entrepreneurs to enhance their status of in the society.

Table Vi Problems Faced By The Women ENTREPRENEURS

\begin{tabular}{|c|l|c|c|}
\hline $\begin{array}{c}\text { S. } \\
\text { No. }\end{array}$ & $\begin{array}{c}\text { Nature of the } \\
\text { Problems }\end{array}$ & $\begin{array}{c}\text { No. of } \\
\text { Respondents }\end{array}$ & Percentage \\
\hline 1 & Financial problem & 45 & 45 \\
\hline 2 & Family problem & 20 & 20 \\
\hline 3 & Marketing problem & 20 & 20 \\
\hline 4 & Other problems & 15 & 15 \\
\hline & Total & 100 & 100 \\
\hline
\end{tabular}

Women entrepreneurs face a number of problems right from the starting of business till running of the business. $45 \%$ of the respondents' major problem is financial problem they face a lot of huddles for meeting financial requirement for the business concern. It is observed that $20 \%$ of the respondents major problem is family conflicts. If women are enters in the field of business, they must face the conflict in the family. They are overburdened with family responsibilities. They spend more time in business as a result they find it difficult to meet the needs of their family members. In such a situation, it will be very difficult to concentrate and run the business successfully. It is shows that $20 \%$ of the respondents' major problem is marketing their products. It is the main problem of women entrepreneurs. They have to depend on middle men for marketing the product. Middle men tend to exploit the women entrepreneurs easily. It revealed that $15 \%$ of the respondents major problems is society's attitude towards women entrepreneurs, male domination, lack confidence, lack of awareness, illiteracy and ignorance about the market condition.

\section{CONCLUSION}

Women entrepreneurship no doubt plays an important role and makes immense contribution for the growth of Indian economy. At present scenario due to modernization, urbanization, globalization and development of education, with increasing awareness, women are now seeking gainful participation in several fields. The entrepreneurship among women will help them in earning money and becoming economically independent. The main problems of women entrepreneurs are lack of awareness, family support and lack of financial support. The growth and development of women entrepreneurs to be enhanced entrepreneurial development is not possible without the participation of women. Therefore, a pleasant and strong environment is needed to be created to enable women to participate actively in the entrepreneurial activities.

\section{REFERENCES}

[1] Kavita Sangolagi \& Mallikarjun. (2018). Women Entrepreneurs Contributor to the society. International Journal of Advancement in Engineering Technology, Management \& Applied Science, 6(1), 1123.

[2] Latha Krishnan \& Kamalanabhan, T. J. (2013, April-June). Entrepreneurial Success and Life Satisfaction among Women Entrepreneurs in Micro-Enterprises. South Asian Journal of Management, 20(2), 41-57.

[3] Pulla Rao, D. (2011). Women Entrepreneurs and socio-economic development, Serial Publications, New Delhi-2.

[4] Pulla Rao, D. (2012). Women entrepreneurship in India Problems and prospects, Abhijeet Publications, New Delhi-2

[5] Reynolds, P. D. (2005). Understanding business creation: Serendipity and scope in two decades of business creation studies. Small Business Economics, 24, 359-364.

[6] Sangolagi, Kavita \& Mallikarjun Alagawadi. (2016, April). Women Entrepreneurs. International Journal of Advancement in Engineering Technology, Management and Applied Science, 3(1), 216-222.

[7] Santhi, M. \& Nagananthini N. (2014). Role and Involvement of Government Agencies and Financial Institutions in the Development of Women Entrepreneurs in Madurai District. SMART Journal of Business Management Studies, 10(1), 61-69

[8] Schumpeter, Joseph, A. (1950). American Institutions and Economic Progress, Lecture delivered to the Walgreen Foundation Chicago, reprinted in: Joseph A. Schumpeter, The Economics and Sociology of Capitalism, edited by Richard Swedberg (Princeton: Princeton University Press, 1991, 438-444.

[9] Singh Kamal. (1992). Women entrepreneurs, Ashish publishing house, New Delhi-2.

[10] Stevenson, H. H. \& Jarillo J. C. (1990). A paradigm of entrepreneurship research: Entrepreneurial management. Strategic Management Journal, 11, 17-27.

[11] Sushma Bavie \& Apoorva Palkar (2015, June), Women Entrepreneurship towards women Empowerment in India: Plan Initiatives. Southern Economist, 1, 7-13. 